\title{
Republicans challenge evidence of man-made climate change
}

Washington. A group of Republicans in the US Senate has told the Clinton administration that they remain suspicious of the scientific evidence for man-made climate change. They oppose any international agreement that would require the United States to limit emissions of greenhouse gases.

Views expressed at a hearing of the Senate Energy and Natural Resources Committee last week indicated that, if Clinton is re-elected in November and he attempts to negotiate a binding international agreement on greenhouse gas emissions, many minds will need changing before the deal can win Senate ratification.

Frank Murkowski (Republican, Alaska), the committee's chairman, said that "the scientific jury is still out over the question" of whether human activities are likely to result in "dangerous, significant, adverse climate change".

Murkowski asked whether the administration, by backing the concept of a binding international agreement on greenhouse gas emissions, was "trying to achieve through the United Nations something it had failed to achieve before Congress".

He repeated the allegation that the recent assessment of climate change by the Intergovernmental Panel on Climate Change (IPCC) had been "heavily edited after what was apparently pressure from policymakers". This claim was first made by the Global Climate Coalition, an industry-backed lobby group.

But Bennett Johnston (Louisiana), the senior Democrat on the committee, jumped to the IPCC's defence. He called the charge "a disgrace", adding that "there is not a shred of evidence of misconduct by any of the scientists involved". Johnston, who has strong ties to the oil and nuclear industries, said that "industry should stop damaging its own credibility by attacking the IPCC report".

Timothy Wirth, under-secretary for global affairs at the State Department, testified that the charges against the IPCC "had been totally refuted by the scientists involved". He added that the Department of Commerce was leading an inter-agency team studying the economic effects of different climate change policies.

Wirth said that industry was being asked to participate in this process, which would help to establish the US position in negotiating an international agreement. But the retirement in November of Johnston a conservative Democrat widely respected on both sides of the Senate - will make more difficult the task of ratifying such an agreement, even if it is reached.

C. M.

\section{Cash rivalry 'fosters neglect of postdoc supervision'}

Washington. The supervision of postdoctoral students is being neglected by supervisors who fear that the students will become rivals for a diminishing 'pot' of research funds, an international meeting at George Washington University (GWU) in Washington, DC, was told last week.

"We are seeing a considerable drop-off in mentoring because [the supervisors] perceive the youngsters as competitors," Julian Jack, deputy chairman of the Wellcome Trust, told the meeting, held to discuss a perceived 'crisis in science'.

Jack promised that the London-based trust - one of the world's largest private sources of medical research funding, distributing over $£ 200$ million (US\$300 million) last year - would act as a "kind of postdoc liberation front", ensuring fairer treatment for the postdoctoral students funded by its grants.

His point was echoed by Robert Pollack, a professor of biology at Columbia University, New York, who recently closed his laboratory to concentrate on teaching. Pollack said that many scientists were asking why they should bother to help a postdoc to get started as an independent scientist if they were shortly going to be competing with that person for funds. He said that, as a result of a "diminished and cynical view of human relations, the education of many young scientists is deeply defective".

The meeting, 'Science in Crisis at the Millennium', which was organized by Horace Freeland Judson, director of GWU's new Center for History of Recent Science, heard of an unfolding crisis across the scientific community. Speakers said the problem was rooted in lack of money to continue the rapid expansion to which the system had become accustomed.

Diminishing civility and 'collegiality' among researchers, the growing number of postdocs competing with their professors for funds, the increased politicization of peer-review panels and lack of effective selfregulation of misconduct were all put forward as what Judson calls "signs and symptoms" of a "deeper malady" in science.

But not everyone agreed these symptoms amount to a crisis. Jack Gibbons, science adviser to President Bill Clinton, admitted that the scientific community faces "enormous challenges" in adjusting to slower funding growth and changing public expectations. But a true crisis, he said, would be approaching the limits of knowledge. "We shouldn't worry; we are quite secure in our ignorance."

The gloomiest prognosis came from Pollack, who argued that a "crisis of scientific morale" has gripped molecular biology, despite continuing productivity and a relatively healthy funding outlook.

"Low morale is not a matter of too little money, nor of too few ideas, but of too little kindness and decency," said Pollack. "It is a failure of custom and manners, a loss of social purpose, a diminution in the ability or the will to distinguish right from wrong and then to act rightly."

Pollack said he shut his laboratory because he was tired of "spending time pawing through the results of expensive, careful experiments just to find bits of bait to put on the hook of another grant application". For most scientists today, he said, "the job is to get the grant"; everything else was a "distraction".

John Ziman, emeritus professor of physics at the University of Bristol in the United Kingdom, argued that sharp changes

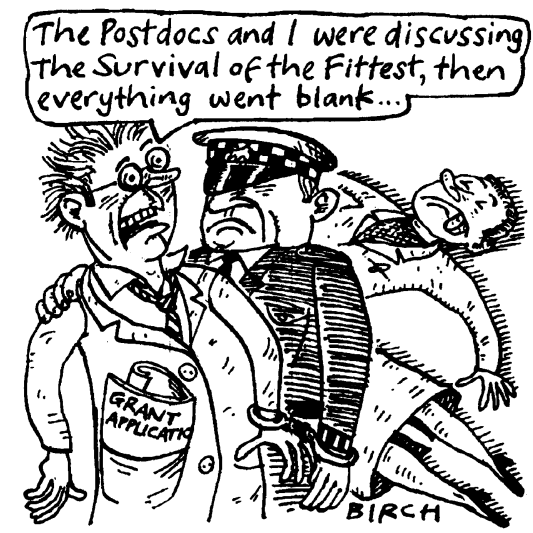

in the language used to discuss science in the past 25 years indicated "a general state of crisis, pervading the whole enterprise from top to bottom". Reeling off a list of the offending words - accountability, allocation, appraisal, career, centre, competition, contract, critical mass - Ziman said that "each of them comes trailing clouds of red tape and disappointment". He pointed out that few were used in this context in 1970. "It's a very big change in such a short time."

The change had come about because the resources available for science, which had been doubling approximately every 15 years for 300 years, "could not conceivably double again". Other problems, Ziman said, "are supplemental to that single fact".

Ziman argues that a new paradigm of "post-academic science" is emerging as a consequence, in which scientists will not normally have tenure, and will engage in projects at the behest of government agencies and industry (see Nature 382, 751; 1996). These scientists would have "neither examples of disinterested behaviour to emulate, nor examples of objectivity to live up to", he warned.

Colin Macilwain 